\title{
HBV DNA loss in Bulgarian patients on NUC therapy. Speed related factors.
}

\section{(NUC related speed of HBV DNA loss in Bulgaria)}

\author{
Donika Krasteva, Radosveta Tomova, Dejan Jelev, \\ Krasimir Antonov, Lyudmila Mateva, Zahariy Krastev
}

Clinic of Gastroenterology, UMHAT "St. Ivan Rilski", Medical University, Sofia, Bulgaria;

\begin{abstract}
Introduction

Approximately 250 million people worldwide are infected with hepatitis B virus (HBV). In Bulgaria data reveal a frequency of HBV infection between 2 and $4 \%$ among the population. With the current therapeutic regimes, we manage to stop viral replication in most of the patients, but not to eradicate the virus.
\end{abstract}

\section{Aim}

The aim of the present study was to determine the time for serum HBV DNA loss in different therapeutic regimes with nucleoside/nucleotide analogues (NUC) in Bulgaria.

\section{Materials and methods}

We analyzed data from 427 patients (304 males and 123 females) treated in the Clinic of Gastroenterology, UMHAT" St. Ivan Rilski", Sofia. All included patients had chronic HBV-infection and had received antiviral NUC therapy for at least 1,5 years. Disease burden was defined clinically and histologically. Patients were followed-up clinically, biochemically and the viral load was determined by a PCR-method. Data were processed by a descriptive analysis, non-parametric tests (Mann-Whitney $U$, Wilcoxon Chi-square) and correlative analysis (Spearman, Pearson, Kendall). 


\section{Results:}

The median patient age was 51,83 $\pm 12,99$ years. $94(22 \%)$ were $\mathrm{HBeAg}(+)$ positive and 333 (78\%) were $\mathrm{HBeAg(-)}$ negative. 111 (26\%) patients had liver cirrhosis and 316(74\%) had chronic hepatitis (244 - FO-F2 stage, and 72 -F3 stage). HBV DNA LOSS was achieved in 409 (95,7\%) patients for a median period of 8,4 months. In 18 patients (4,3\%) HBV DNA loss was not achieved (14,9\% of $H B e A g(+)$ patients and $0,3 \%$ of the HBeAg (-) group). Cirrhotic patients had the fastest HBV DNA loss $(6,1$ months) irrespectively of their sex, age, therapeutic regime or viral load $(p<0,0001)$. Patients treated with Tenofovir and Entecavir had slower loss than those, treated with Lamivudin $(p<0,0001)$. The latter group had lower viral load at baseline, and 9,4\% were $\mathrm{HBeAg}(+)$. Significant correlation was established between the HBV DNA loss rate and the viral load $(p<0,0001)$.

\section{Conclusion}

In our patients the viral response rate depended on the viral load and HBeAg status. No influence of therapeutic regime was established. Patients with liver cirrhosis had the fastest HBV DNA serum loss, though they did not have the lowest viral load. In HBe negative group older women (above 60) had the slowest viral loss and the older men had the fastest. In $\mathrm{HBe}(+)$ group the patient number is small for determination of sex differences, but there is a tendency for slower (approximately 16 months) loss in the youngest.

\section{Keywords: hepatitis B, nucleotide therapy, viral loss}

\section{Introduction}

Approximately 250 million people worldwide are infected with hepatitis B virus (HBV). In Bulgaria data reveal a frequency between 2 and $4 \%$ of HBV infection among the population. With the current therapeutic regimes we manage to stop viral replication in most of the patients, but not to eradicate the virus.

\section{Materials and methods}

We analyzed data from 427 patients (304 males and 123 females) treated in the Clinic of Gastroenterology, UMHAT "St. Ivan Rilski", Sofia. All included patients had chronic HBV-infection and had received antiviral NUC therapy for at least 1,5 years. Disease burden was defined clinically and histologically. Patients were followed-up clinically, biochemically and the viral load was determined by a PCR-method. Data were processed by a descriptive analysis, non-parametric tests (Mann-Whitney U,Wilcoxon Chi-square) and correlative analysis (Spearman, Pearson, Kendall).

\section{Aim}

The aim of the present study was to determine the time for serum HBV DNA LOSS in different therapeutic regimes with nucleoside/nucleotide analogues (NUC) in Bulgaria and to analyze different factors that could contribute to the speed of loss. 


\section{Results}

\section{DEMOGRAPHIC DATA AND PATIENT DISTRIBUTION HBE STATUS}

From 427 patients - $333(78 \%)$ were HBeAg (-) negative and 94 patients (22\%) were HBeAg (+) positive. Distribution according to sex and HBe status is presented in table 1.

Table 1. Distribution according to sex and HBe status

\begin{tabular}{|c|c|}
\hline Male HBe $(-)$ negative & Female HBe $(-)$ negative \\
\hline $\mathrm{n}=\mathbf{2 3 0}$ & $\mathrm{N}=103$ \\
\hline Male $\mathrm{HBe}(+)$ positive & Female $\mathrm{HBe}(+)$ positive \\
\hline $\mathrm{n}=\mathbf{7 4}$ & $\mathrm{N}=\mathbf{2 0}$ \\
\hline
\end{tabular}

\section{STAGE OF FIBROSIS}

111 (26\%) patients had liver cirrhosis and 316 (74\%) were with chronic hepatitis. 244 patients had F0 - F2 fibrosis and 72 patients - had F3 fibrosis (fig. 1)

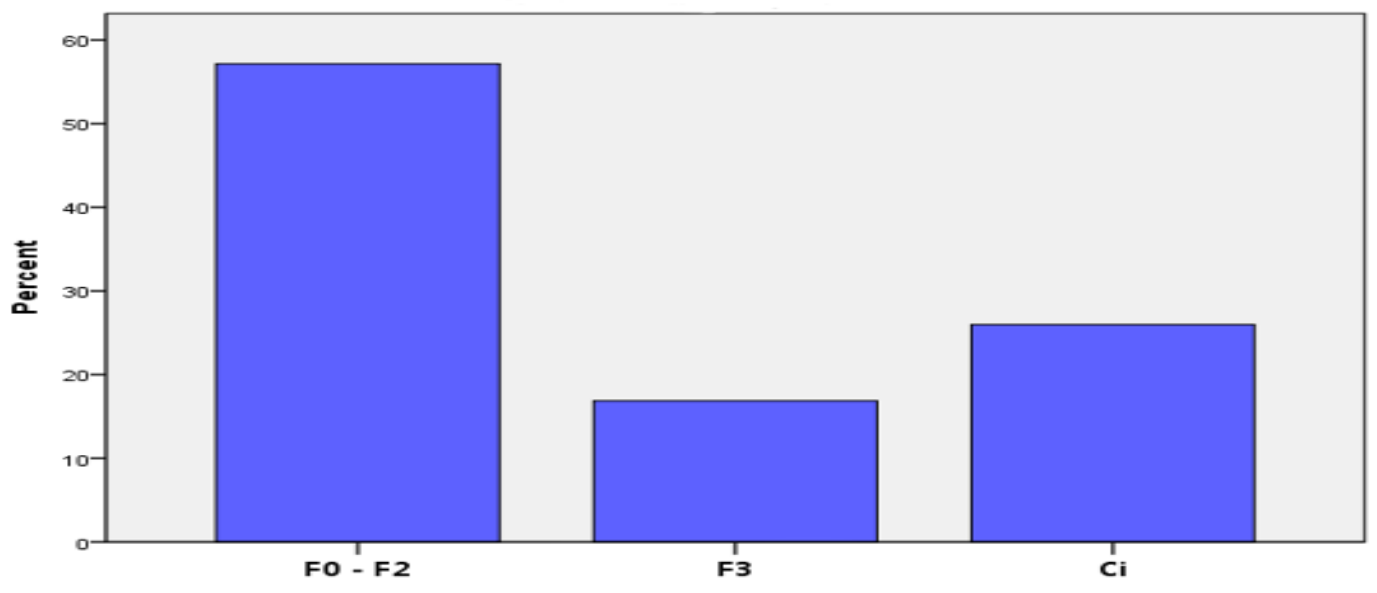

Figure 1. Distribution according to the stage of fibrosis

\section{AGE}

The average age of the patients was $51,83 \pm 12,99$ years, $51,07 \pm 13,01$ (in males) and $53,71 \pm 12,82$ (in females) respectively.

The average age in $\mathrm{HBe}(+)$ positive group was 42,17 years, and in the $\mathrm{HBe}(-)$ negative group was 54,56 years. 


\section{VIRAL LOAD}

No significant difference in viral load was registered between $\mathrm{HBeAg}(+)$ and $\mathrm{HBe}(-)$ patients as long as in viral load in males and females in both groups. (table 2 and figure 2 )

Table 2. Viral load in males and females in $\mathrm{HBe}(+)$ and $\mathrm{HBe}(-)$ patients

\begin{tabular}{|l|c|c|}
\hline \multicolumn{1}{|c|}{$\begin{array}{c}\text { HBV DNA } \\
\text { log/ml }\end{array}$} & HBe(+) & HBe(-) \\
\hline male & $9,28 \pm 9,22$ & $8.29 \pm 9.2$ \\
\hline female & $9,03 \pm 9,20$ & $8.55 \pm 9.20$ \\
\hline
\end{tabular}

No significant difference in viral load was also registered in different age subgroups. (table 3)

Table 3. HBV DNA level in different age subgroups

\begin{tabular}{|c|c|c|c|}
\hline HBV DNA & $\begin{array}{c}\text { Age }<\mathbf{4 0} \text { yrs } \\
\mathbf{n}=\mathbf{5 5}\end{array}$ & $\begin{array}{c}\text { Age 41-60 yrs } \\
\mathbf{n}=\mathbf{1 7 9}\end{array}$ & $\begin{array}{c}\text { Age }>\mathbf{6 0} \text { yrs } \\
\mathbf{n}=\mathbf{9 9}\end{array}$ \\
\hline log/ml & $8,56 \pm 9,02$ & $8,38 \pm 9.98$ & $8,29 \pm 9.83$ \\
\hline
\end{tabular}

\section{THERAPEUTIC REGIME}

269 (63\%) of patients were treated with Tenofovir, 85 (19,9\%) with Lamivudin, 63 (14,8\%) with Entecavir and 10 (2,3\%)with Telbivudine.(figure 2) 


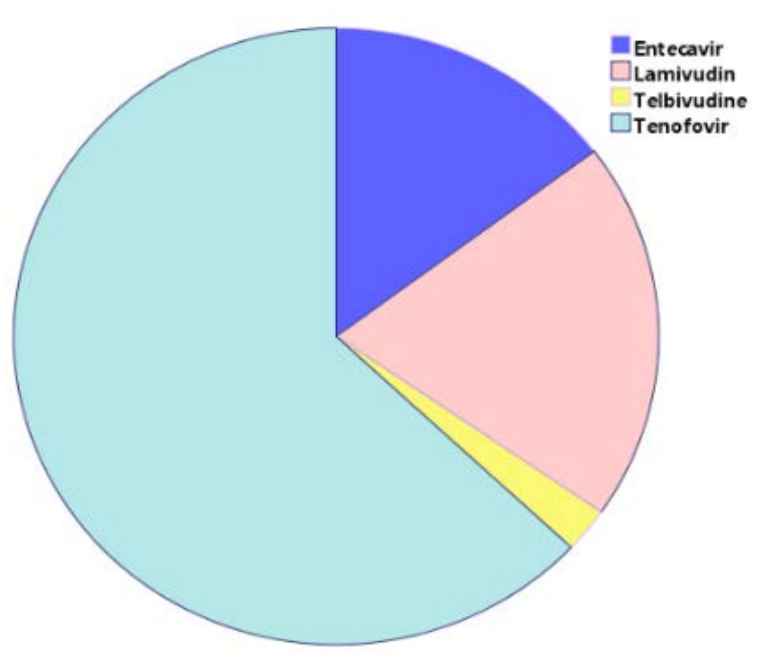

Figure 2. Distribution according to therapy regime

\section{HBV DNA LOSS}

In 409 (95,7\%) patients sustained undetectable serum HBV DNA was achieved for approximately 8,4 months. HBV DNA LOSS was not achieved in 18 patients (4,3\%), followed for at least 36 months: in $14,9 \%$ from the $\mathrm{HBeAg}(+)$ group, and in $0,3 \%$ from the HBeAg (-) group.

\section{SPEED OF HBV DNA LOSS AND VIRAL LOAD}

Statistically significant correlation between speed of HBV DNA LOSS and viral load was established- $(p<$ 0,0001). (figure 3)

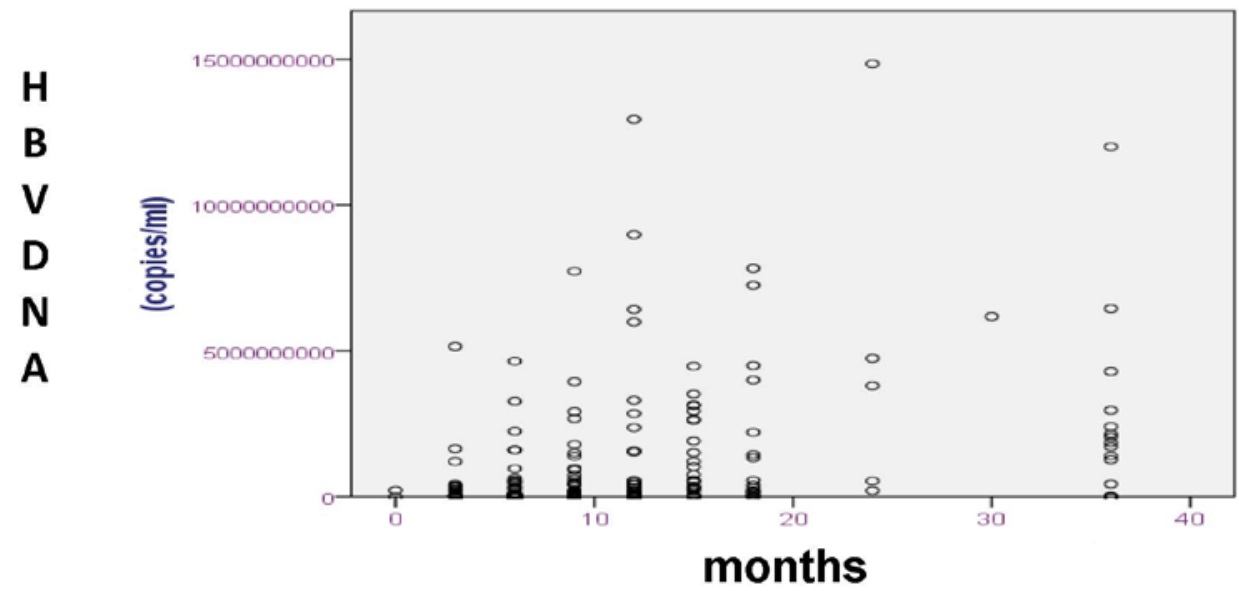

Figure 3. Viral load and speed of HBV DNA loss 


\section{HBEAG STATUS AND NUC INDUCED HBV DNA LOSS}

In $\mathrm{HBe}(-)$ patients with chronic hepatitis B (presumably with genotype D) HBV DNA loss was achieved within 7 months (median 6,64 $\pm 5,26$ ). In male patients this took a month less than in females $(6,2 \pm 7,7$ in males and 7,7 $\pm 7,59$ in females respectively). (figure 4)

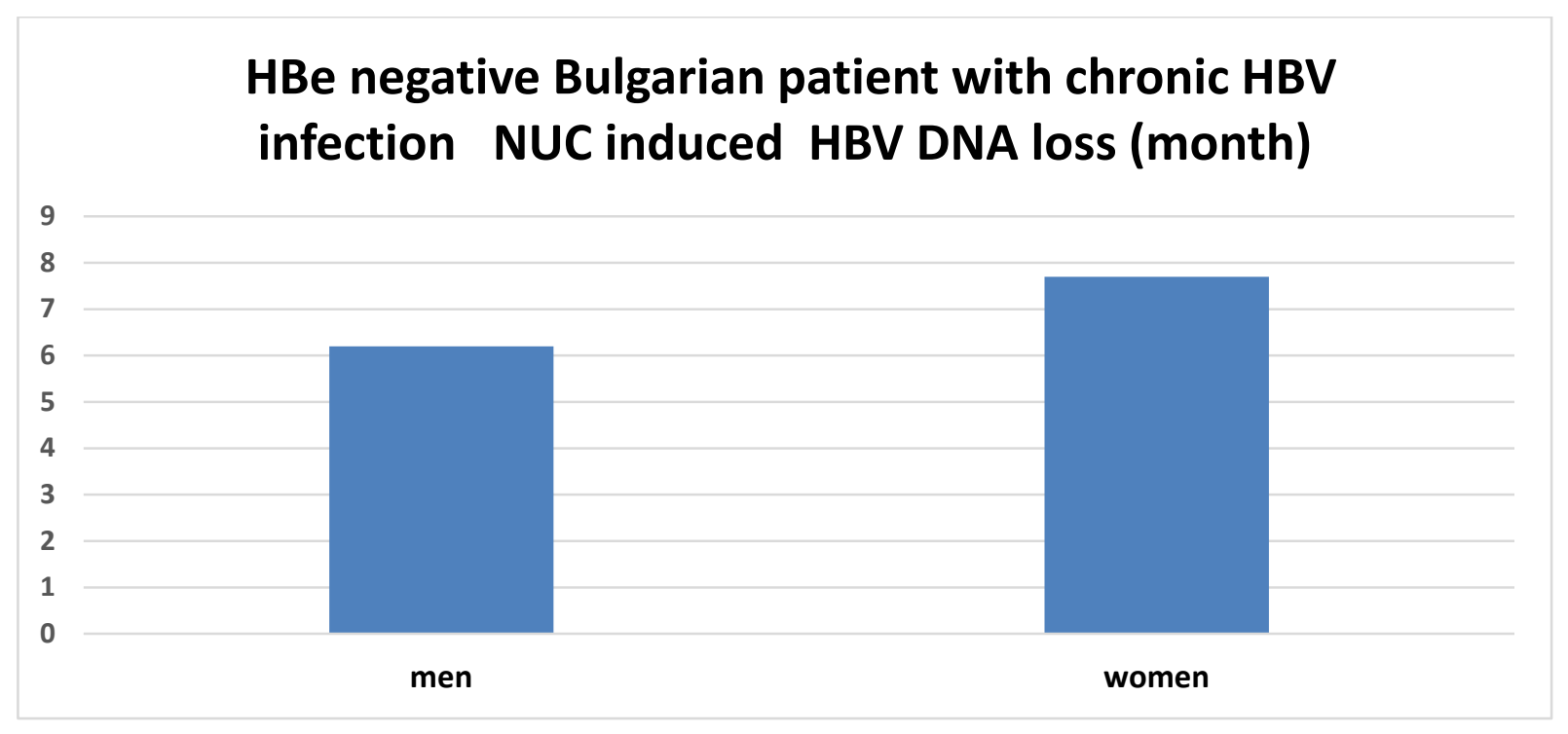

Figure 4. Speed of HBV DNA loss in the HBe(-) group and sex

This could not be explained with higher viral load in females (females - HBV DNA $8.55 \pm 9.2 \mathrm{log} / \mathrm{m}$ and males - HBV DNA $8.29 \pm 9.20 \mathrm{log} / \mathrm{ml})$. The age was also not a factor as long as women were approximately 2 years older than men in the $\mathrm{HBe}(-)$ group (median age $54,56 \pm 13,22$ ), median female age $54.8 \pm 11.9$ and median male age $53 \pm 11.7$ ). (figure 5 ) Additional analysis revealed that older women (above 60) had the slowest viral loss (8.21 \pm 5.99 months) and the older men had the fastest (5.85 \pm 6.02 months). (table 4) 
Table 4. Speed of HBV DNA loss in the HBe(-) group

\begin{tabular}{|c|c|c|c|c|c|c|}
\hline $\begin{array}{c}\text { HBe (-) } \\
\text { group } \\
\text { n=333 }\end{array}$ & \multicolumn{3}{|l|}{ Baseline HBV DNA log/ml } & \multicolumn{3}{c|}{ HBV DNA loss (months) } \\
$6,64 \pm 5,26$ \\
\hline & $\begin{array}{c}\text { For the } \\
\text { subgroup }\end{array}$ & men & women & $\begin{array}{c}\text { For the } \\
\text { subgroup }\end{array}$ & men & women \\
\hline $\begin{array}{c}\text { Age }<40 \\
\text { yrs } \\
n=55\end{array}$ & $8,56 \pm 9,02$ & 8,49 & $8,8 \pm 9.04$ & $6,65 \pm 5,89$ & $\begin{array}{c}6.78 \pm 10.28 \\
n=42\end{array}$ & $\begin{array}{c}6.23 \pm 10.46 \\
n=13\end{array}$ \\
\hline $\begin{array}{c}\text { Age } 41- \\
60 \text { yrs } \\
n=179\end{array}$ & $8,38 \pm 9.98$ & 8,33 & $8,54 \pm 9.1$ & $6,58 \pm 5,24$ & $\begin{array}{c}6.23 \pm 6.06 \\
n=127\end{array}$ & $\begin{array}{c}7.44 \pm 6.09 \\
n=52\end{array}$ \\
\hline $\begin{array}{c}\text { Age }>60 \\
\text { yrs } \\
n=99\end{array}$ & $8,29 \pm 9.83$ & 8,14 & $8,46 \pm 8,96$ & $6,75 \pm 4,06$ & $\begin{array}{c}\mathbf{5 . 8 5} \\
\mathbf{n}=\mathbf{6 1}\end{array}$ & $\begin{array}{c}\mathbf{8 . 2 1} \pm 5.99 \\
\mathbf{n}=\mathbf{3 8}\end{array}$ \\
\hline
\end{tabular}

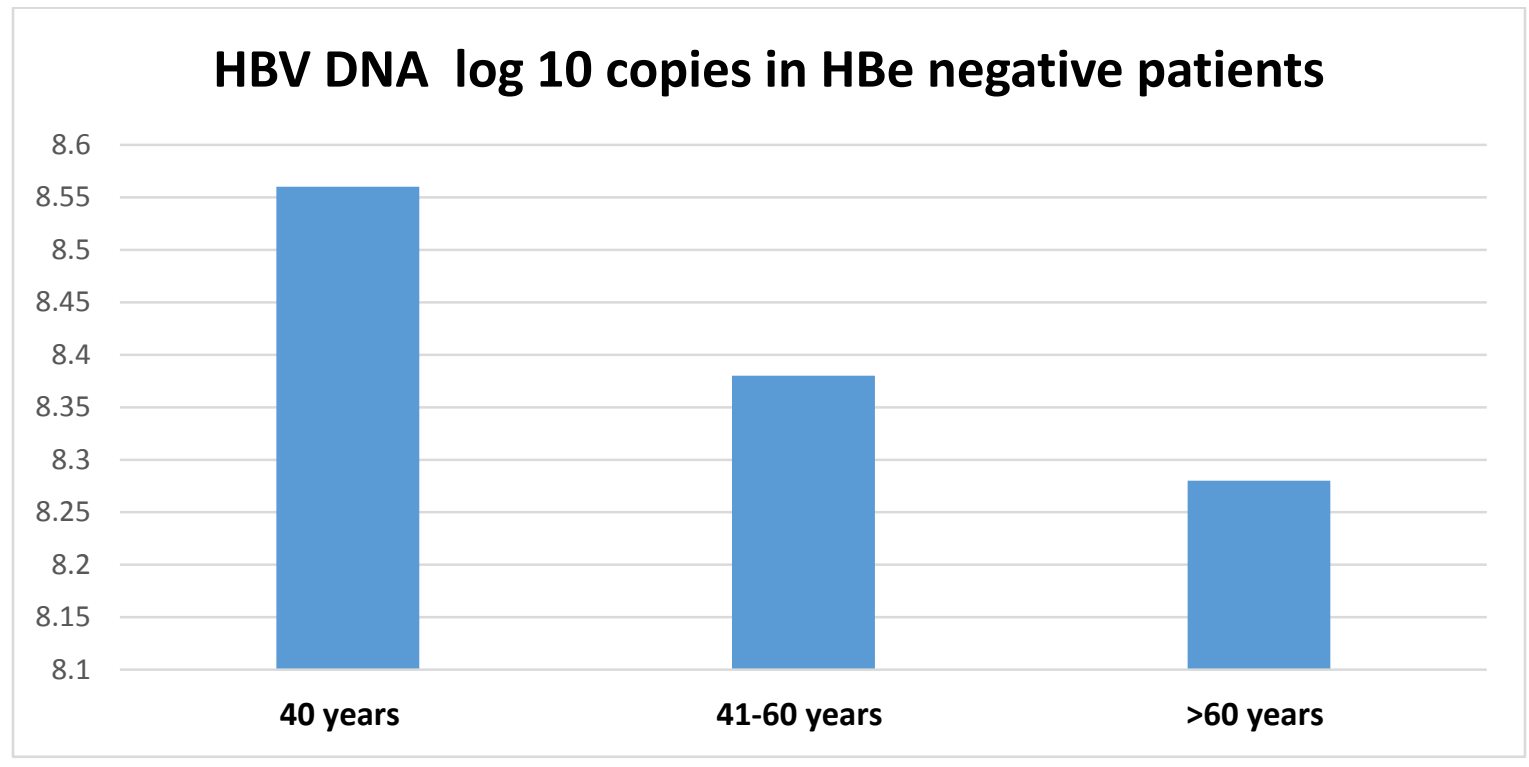

Figure 5. HBV DNA levels in $\mathrm{HBe}(-)$ patients in different age subgroups

In the HBeAg (+) group (94 patients-22\%) the median age was $42,17 \pm 12,46$ years. Again women ( $41.9 \pm 12.3$ years) were approximately 2 years older than men ( $40.0 \pm 12.8$ years).

There was no difference between HBV DNA loss in males ( $n=74-14.39 \pm 7.55$ months) and females $(n=20-15- \pm 7.74$ months). (table 5) 
Table 5. Speed of HBV DNA loss in the HBe(+) group

\begin{tabular}{|c|c|c|c|c|}
\hline \multirow{2}{*}{$\begin{array}{c}\text { HBe (+) } \\
\text { group } \\
\mathrm{n}=94\end{array}$} & Baseline HBV DNA log/ml & \multicolumn{3}{|c|}{$\begin{array}{c}\text { HBV DNA LOSS months } \\
14,52 \pm 7,56\end{array}$} \\
\hline & For the subgroup & $\begin{array}{l}\text { For the } \\
\text { subgroup }\end{array}$ & men & women \\
\hline $\begin{array}{c}\text { Age }<40 \\
\text { yrs } \\
n=56 \\
\end{array}$ & $9,28 \pm 9.4$ & $16,28 \pm 10,20$ & $\begin{array}{c}16.36 \pm 10.20 \\
n=44\end{array}$ & $\begin{array}{c}16.00 \pm 10.27 \\
n=12\end{array}$ \\
\hline $\begin{array}{c}\text { Age 41- } \\
60 \text { yrs } \\
n=28\end{array}$ & $9,14 \pm 9.14$ & $12 \pm 6,41$ & $\begin{array}{c}11.6 \pm 6.41 \\
n=23\end{array}$ & $\begin{array}{l}13.8 \\
n=5\end{array}$ \\
\hline $\begin{array}{c}\text { Age }>60 \\
\text { yrs } \\
n=10\end{array}$ & $9,28 \pm 9,08$ & $11,7 \pm 6,03$ & $\begin{array}{c}11.14 \pm 6.03 \\
n=7\end{array}$ & $\begin{array}{c}13.00 \\
n=3\end{array}$ \\
\hline
\end{tabular}

In the $\mathrm{HBe}(+)$ patients mean HBV DNA level did not differ significantly between males $(8,29 \pm 9,2 \mathrm{log} / \mathrm{ml})$ and females $(8,55 \pm 9,2 \mathrm{log} / \mathrm{ml})$. In $\mathrm{HBe}(+)$ patients under 40 years loss is slower for approximately 16 months in both sexes (males $n=44-16.36 \pm 10.20$ and females $n=12-16.00 \pm 10.27$ ).

The $\mathrm{HBe}(+)$ patients achieved HBV DNA loss twice slower than $\mathrm{HBe}(-)$ group (median 14,52 \pm 7,56 months).(figure 6)

\section{NUC induced HBV DNA loss (month) in Bulgarian patient with chronic HBV infection}

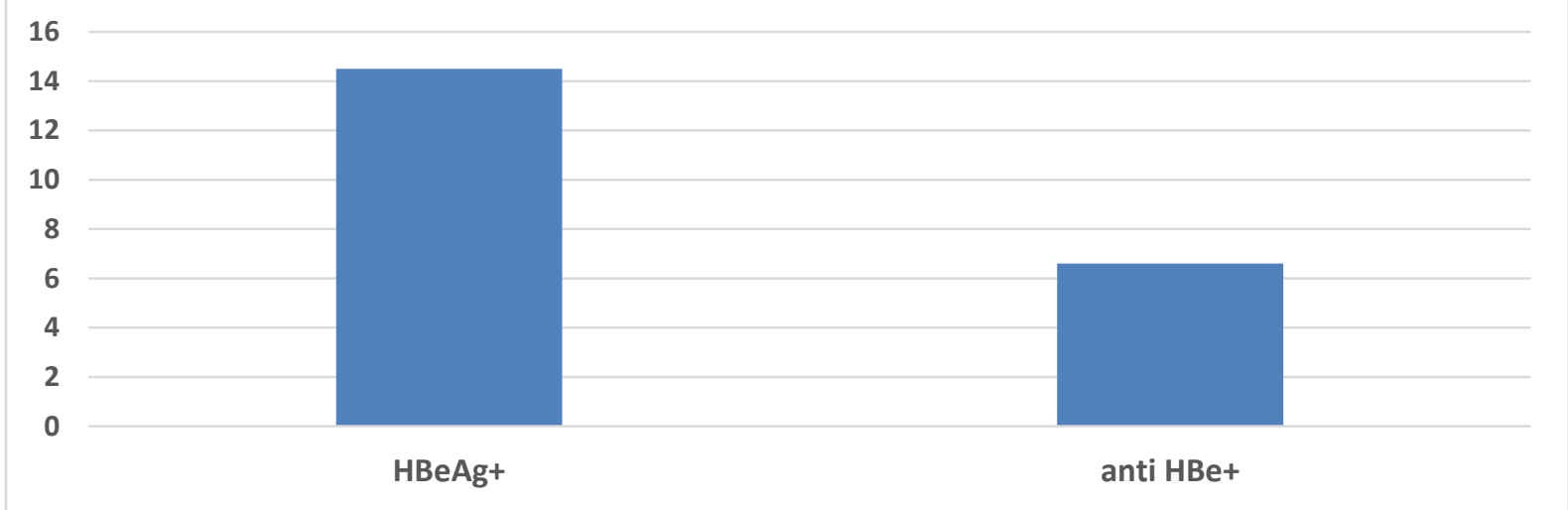

Figure 6. Comparison between months for HBV DNA loss in $\mathrm{HBe}(+)$ and $\mathrm{HBe}(-)$ patients 
In $\mathrm{HBe}(-)$ group time to HBV DNA loss in women increases with age, while in men decreases. In $\mathrm{HBe}(+)$ group the patient number is small for determination of sex differences, but there is a tendency for slower loss in the youngest.

\section{LIVER FIBROSIS}

In chronic hepatitis the speed of HBV DNA LOSS decreases in histological activity and increases in advanced fibrosis. (figure 7)

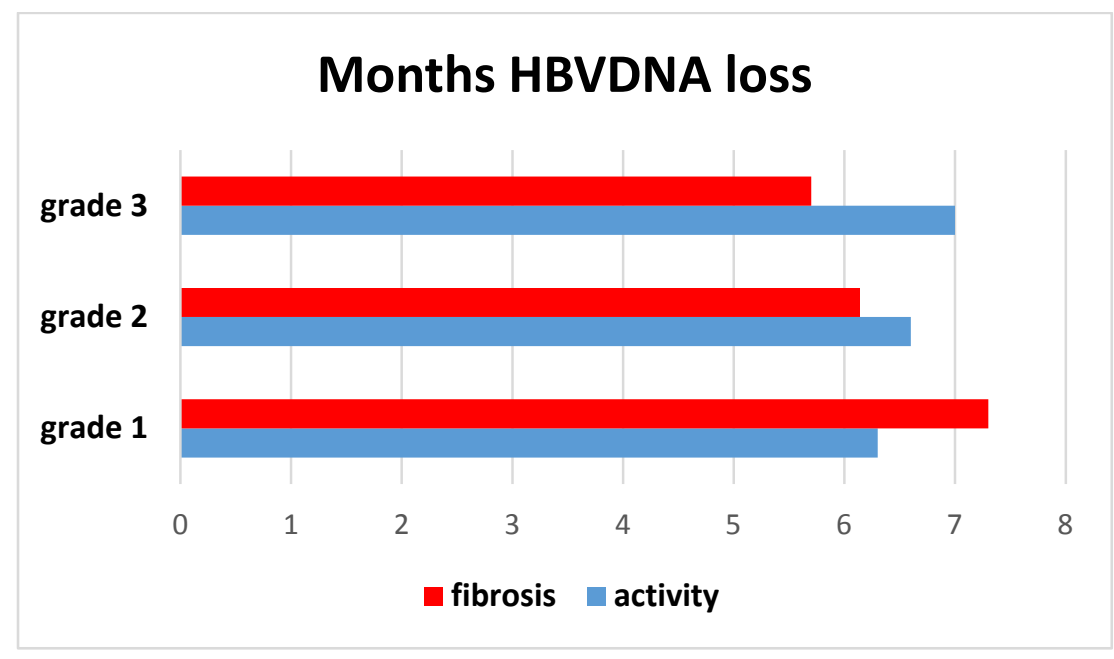

Figure 7. Relationship between liver fibrosis and time to HBV DNA loss

The fastest LOSS of serum HBV DNA was registered in patients with liver cirrhosis (6,1 months) irrespectively of sex, age, therapeutic regime or viral load of the patients $(p<0,0001)$. (figure 8$)$

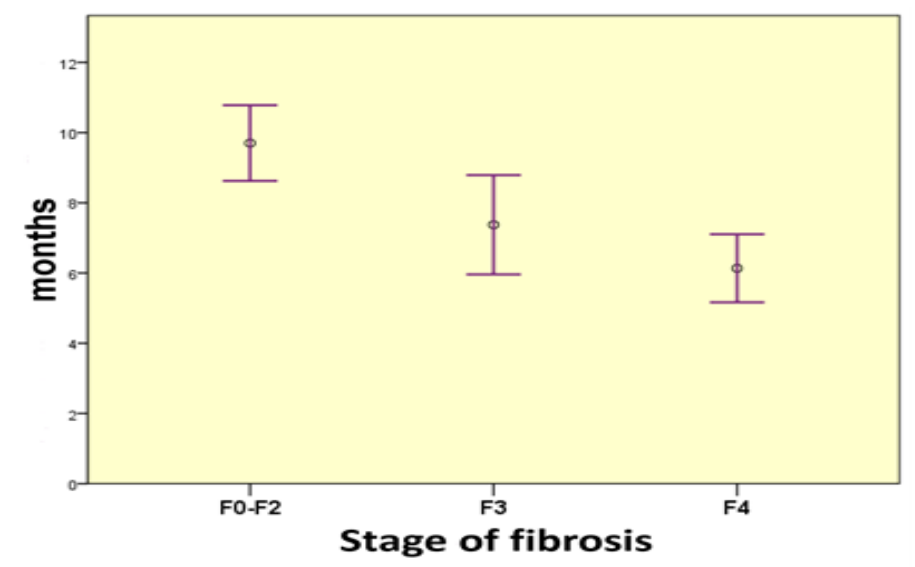

Figure 8. Stage of fibrosis and time of HBV DNA loss 


\section{DRUGS}

Patients treated with Tenofovir and Entecavir needed more time for achieving sustained undetectable viral load than those treated with Lamivudin, p<0,0001.(table 6) 9,4\% of patients treated with Lamivudin were $\mathrm{HBeAg}(+)$ positive and had lower viral load at baseline.

Table 6. Therapeutic regime and time for HBV DNA loss

\begin{tabular}{|c|c|}
\hline Drug & months \\
\hline Lamivudin & $5,86 \pm 5,75$ \\
\hline Tenofovir & $9,1 \pm 5,90$ \\
\hline Entecavir & $8,9 \pm 8,33$ \\
\hline
\end{tabular}

\section{Discussion}

Chronic infection with hepatitis B is associated with complications such as liver cirrhosis and risk of developing hepatocellular carcinoma. In such patients persistent viral replication is associated with progression of liver disease and treatment is aimed at maximal viral suppression. In hepatitis B e-antigen (HBeAg) positive chronic hepatitis $B$, spontaneous or treatment-induced clearance of $\mathrm{HBeAg}$ and seroconversion to anti-HBe is typically followed by a long-term period of low-level replication. In HBeAgnegative patients the aim of antiviral treatment is a virologic and biochemical response with undetectable or suppressed HBV DNA and normalization of aminotransferase levels. After antiviral therapy termination a relapse within different periods of time is commonly observed. For both, chronic HBeAg-positive and negative patients, HBsAg seroconversion to anti-HBs would be the best option, however this is rarely achieved. Longer treatment with TDF and ETV is associated with higher HBV DNA loss rates (98\%-99\%), and higher HBeAg and HBsAg loss and seroconversion rates [2].

Pretreatment predictors of virologic response in patients with chronic hepatitis B are important tools for selection of optimal antiviral therapy. In interferon alfa and pegylated interferon alfa-treated patients, low baseline HBV DNA concentrations, HBV genotype A (B), and high baseline ALT levels are significantly associated with treatment response. [1]. In patients treated with nucleos(t)ide analogues, low baseline HBV DNA but not viral genotype is positively associated with virologic response./ 1 / During treatment the best predictor of response is HBV DNA kinetics. Early viral suppression is associated with favourable virologic response and reduced risk for subsequent resistance mutations. In NUC-treated patients some conflicting data exist but generally no effect of genotype on treatment outcome was observed .(1)

Low baseline viral load levels is considered to be predictive of favourable virologic response in patients with chronic hepatitis B on different treatment regimens.(1) In our study patients treated with Tenofovir and Entecavir had slower loss than those, treated with Lamivudin. Significant correlation was established between HBV DNA loss rate and the viral load which is in accordance with data from other studies.

No correlation was found between ethnicity and NUC treatment response. Regarding the age and gender there are different data. (1). In our study no influence of sex, age or the therapeutic regime was established. Though a slight tendency for faster viral loss in older men ( $>60$ years) compared to older women (>60 years) in the $\mathrm{HBe}(-)$ subgroup was observed. 
The $\mathrm{HBe}(+)$ patients achieved HBV DNA loss twice slower than $\mathrm{HBe}(-)$ group (median 14,52 $\pm 7,56$ months). In HBeAg positive patients, baseline factors predictive of antiHBe seroconversion in the literature are low viral load, high serum ALT levels, and high activity scores on liver biopsy [3]. HBV genotype did not influence the virological response to any of the available NUCs $[3,4]$. In other studies the presence of cirrhosis and absence of HBeAg at baseline were independent predictors of earlier clearance of serum HBV DNA [5].In our group of patients the fastest LOSS of serum HBV DNA was registered in patients with liver cirrhosis (6,1 months) irrespectively of sex, age, therapeutic regime or viral load of the patients.

\section{Conclusion}

In our patients speed of viral response depended on the viral load and HBeAg status and was not influenced by therapeutic regime. The fastest HBV DNA serum loss was registered in cirrhotic patients, who had the lowest viral load. In HBe negative group older women (above 60 years) had the slowest viral loss and the older men had the fastest. In $\mathrm{HBe}(+)$ group the patient number is small for determination of sex differences, but there is a tendency for slower (approximately 16 months) loss in the youngest.

\section{References}

1. Annika Kau, Johannes Vermehren, Christoph Sarrazin. Treatment predictors of a sustained virologic response in hepatitis B and C. Journal of Hepatology 49 (2008) 634-651.

2. Ezequiel Ridruejo. Treatment of chronic hepatitis B in clinical practice with entecavir or tenofovir. World J Gastroenterol. 2014 Jun 21; 20(23): 7169-7180.

3. European Association For The Study Of The Liver. EASL clinical practice guidelines: Management of chronic hepatitis B virus infection. J Hepatol. 2012;57:167-185.

4. Kim BK, Revill PA, Ahn SH. HBV genotypes: relevance to natural history, pathogenesis and treatment of chronic hepatitis B. Antivir Ther. 2011;16:1169-1186.

5. Marengo A, Bitetto D, D'Avolio A, Ciancio A, Fabris C, Marietti M, Toniutto P, Di Perri G, Rizzetto M, Marzano A. Clinical and virological response to entecavir in HBV-related chronic hepatitis or cirrhosis: data from the clinical practice in a single-centre cohort. Antivir Ther. 2013;18:87-94.

\section{Corresponding author:}

Donika Krasteva, Clinic of Gastroenterology, UMHAT "St. Ivan Rilski", Medical University, Sofia, Bulgaria

Fax.: +359 28519816

Email: donika.krysteva@gmail.com 